\title{
Thermodynamic Analysis of Gas Turbine - Solid Oxide Fuel Cell (GT-SOFC) Aircraft Auxiliary Power Unit (APU)
}

\author{
Fatih TUNCA, Nevzet KAYA
}

\begin{abstract}
In this paper, Gas Turbine - Solid Oxide Fuel Cell (GT-SOFC) Aircraft Auxiliary Power Unit (APU) configuration is thermodynamically investigated. The system has a single stage centrifuge compressor, a heat exchanger, a jet fuel reformer, a SOFC, a combustion chamber and a turbine. The onboard kerosene fuel is converted to $\mathrm{H}_{2}$ and $\mathrm{CO}$ in the jet fuel reformer and used in the SOFC. Excess gases from the SOFC and additional kerosene from the fuel tank are burned in the combustion chamber. The system efficiency is increased significantly decreasing the overall fuel consumption. Although the system total weight increases with the additional elements such as SOFC, heat exchanger and jet fuel reformer, $\mathrm{H}_{2} \mathrm{O}$ produced in the SOFC can be used as potable water in the aircraft decreasing the water supply need and balancing the take-off weight of the aircraft.
\end{abstract}

Index Terms - Aircraft Auxiliary Power Unit (APU), GT-SOFC, Hybrid Power Units, Thermodynamic Analysis.

\section{INTRODUCTION}

Effect of aviation to anthropogenic $\mathrm{CO}_{2}$ emission is $2.5 \%$ [1]. Demand for air traffic is rapidly grooving. According to Boeing Market Outlook World GDP will grow 3.1\%, commercial aircraft fleet will grow $3.6 \%$ and air traffic will grow 4,9\% yearly between 2014 and 2034 [2]. According to Airbus Global Market Forecast, yearly air traffic growth will be $4.5 \%$ between 2015 and 2035 [3]. Both Airbus and Boeing which are the biggest aircraft suppliers in the world, forecast 4-5\% yearly growth in air traffic between 2015 and 2035. This indicator forces industries and research organizations to investigate more economical and environmental systems and operations so as to minimize operation costs and environmental effects of air travel.

Aircraft's main engines provide the power needed for thrust and systems consumption. There are 3 types of power sources for aircraft systems; electrical, hydraulic and pneumatic as seen in Table I. Electrical systems are more efficient and have lower weight than other power sources. Therefore, aircraft manufacturers are recently directed to More Electric Aircraft (MEA) approach. There would be All Electric Aircraft (AEA) approaches even in the long term strategies so as to minimize environmental effect of aircrafts. By shifting conventional systems power sources from hydraulic and pneumatic to electrical devices there would be significant weight advantages which will further decrease the fuel used. Electrical systems are more advantageous in term of reliability and maintenance costs too.

Anadolu University, Eskisehir, TURKIYE
Boeing 787 is one of the best examples of moving towards MEA approach. Boeing 787 introduced no-bleed system to increase the efficiency and reduce fuel consumption. The predicted operational fuel efficiency is $3 \%$ with no-bleed architecture. On Boeing 787, the bleed air is used in cowl de-icing system only, while wing de-icing system, engine start system, hydraulic pump drives and cabin environmental control system are electrified. The new electrical architecture decreased the system weight, reduced part numbers, increased reliability and improved performance of the aircraft. Since the bleed air need is decreased, a simpler APU architecture producing electric power only is mounted on the aircraft [5].

TABLE I

AIRCRAFT POWER SOURCES [4]

\begin{tabular}{lll}
\hline \hline Power Source & Conventional System & \multicolumn{1}{c}{ New Approach - MEA } \\
\hline & & Cabin Lighting, \\
& & Avionics, \\
& Cabin Lighting, & Fuel Pumps, \\
Electrical & Avionics, & Brakes, \\
& Fuel Pumps, etc. & Flight Controls, \\
& & Engine start, \\
& & De-icing, \\
& & ECS \& Pressurization, etc. \\
& Brakes, & \\
Hydraulic & Flight Controls, & Flight Controls, \\
& Landing Gear, etc. & Landing Gear, etc. \\
& Engine start, & \\
Pneumatic & De-icing, & Cowl De-icing \\
& ECS \& Pressurization & \\
\hline \hline
\end{tabular}

APUs; typically provides bleed air for main engine start, air condition system and de-icing system as well as electrical energy which is necessary for the aircraft systems such as back-up purposes during flight or on the ground. Auxiliary Power Units (APU) that are used for commercial aircrafts are gas turbine engines. They generally have a single stage centrifuge compressor, a combustion chamber, a single stage turbine and other accessories. Their thermal efficiencies are as low as $15 \%$ [6]. Although they use less fuel than main aircraft engines their environmental effects are significant as seen in table II [7]. 
TABLE II

COMPARISON OF FUEL CONSUMPTION AND EMISSIONS FOR JT8D-219 AND HONEYWELL GTCP 131 [7]

\begin{tabular}{lcrrr}
\hline \hline & $\begin{array}{c}\text { Power } \\
\text { Rate }\end{array}$ & $\begin{array}{c}\text { Fuel } \\
\text { Consumption } \\
(\mathrm{kg} / \mathrm{s})\end{array}$ & $\mathrm{HC} \mathrm{mg/ \textrm {m } ^ { 3 }}$ & $\begin{array}{c}\mathrm{NO}_{\mathrm{X}} \\
\mathrm{Mg} \\
\mathrm{NO}_{2} / \mathrm{m}^{3}\end{array}$ \\
\hline $\begin{array}{l}\text { JT8D-219 } \\
\text { (Main Eng.) }\end{array}$ & Idle & 0.13 & 2.1 & 3.8 \\
$\begin{array}{l}\text { Honeywell } \\
\text { GTCP 131 } \\
\text { (APU) }\end{array}$ & Normal & 1.4 & 3.6 & 32 \\
\hline \hline
\end{tabular}

The Honeywell 131-9A gas turbine APU has $440 \mathrm{~kW}$ shaft power and $90 \mathrm{~kW}$ electric generator. The APU weight is 163,7 $\mathrm{kg}$ and consumes $120 \mathrm{~kg}$ fuel per hour [8,9]. This type of APU is generally used in narrow body aircrafts. Narrow body aircrafts represent $\% 65$ of commercial aircraft fleet in 2014 and will represent $\% 70$ of commercial aircraft fleet in 2034 [2].

There are two different fuel cell application strategies in aircrafts. First strategy is storing hydrogen onboard aircraft and then using it in low temperature, high power density fuel cells. PEM fuel cells can be used for this strategy. In this case; hydrogen storage equipment must be installed on the aircraft and hydrogen refueling stations must be established at the airports. Second strategy is coupling high temperature fuel cells with gas turbine engines, reforming onboard kerosene to $\mathrm{H}_{2}$ and using it in fuel cell. SOFC fuel cells can be used for this strategy. This strategy would be eliminating hydrogen storage equipment in aircraft and hydrogen refueling stations at the airports. High temperature fuel cells are heavier than low temperature fuel cells. Therefore, weight estimations should carefully be performed for both strategies. Table III shows the weight effect of fuel cell utilization strategies.

TABLE III

High TEMPERATURE AND LOW TEMPERATURE FUEl CELl WEIGHT EFFECT

\begin{tabular}{lll}
\hline \hline & \multicolumn{1}{c}{$\begin{array}{c}\text { Low Temperature Fuel } \\
\text { Cell }\end{array}$} & \multicolumn{1}{c}{$\begin{array}{c}\text { High Temperature Fuel } \\
\text { Cell }\end{array}$} \\
\hline $\begin{array}{l}\text { Fuel Cell Weight } \\
\text { Increase }\end{array}$ & Low & High \\
Jet Fuel Reformer & Not needed & Needed \\
Heat Exchanger & Not needed & Needed \\
$\mathrm{H}_{2}$ Storage Unit & Needed & Not needed
\end{tabular}

APU power densities are around $2,5-3 \mathrm{~kW} / \mathrm{kg}$. Therefore, proposed system should have high power densities so as to be competitive. Solid Oxide Fuel Cells have higher efficiencies than Gas Turbine Engines and they can be easily coupled with Brayton Cycle in which gas turbine engines operate. State of the art of SOFC power density is around $300 \mathrm{~W} / \mathrm{kg}$ while NASA develops $700 \mathrm{~W} / \mathrm{kg}$ high power density SOFC stacks [10].

Fuel Cells consume less fuel and produce water during operation. This water can be used as potable water in the aircraft. Potable water in the aircraft is used in galleys and toilets and then stored in waste system. Airbus A320 has 200 litters water tank, which is pressurized with bleed air during flight. The system uses service panel pressure ports, when the aircraft is on the ground, [11].

\section{II.METHODOLOGY}

\section{A. Assumptions}

The system schematic is shown in figure 1 . The system is assumed to work in steady state conditions. Compressor inlet parameters are chosen as their values at sea level conditions. All the thermodynamic performances of the hybrid system were calculated by a code developed in the MATLAB software.

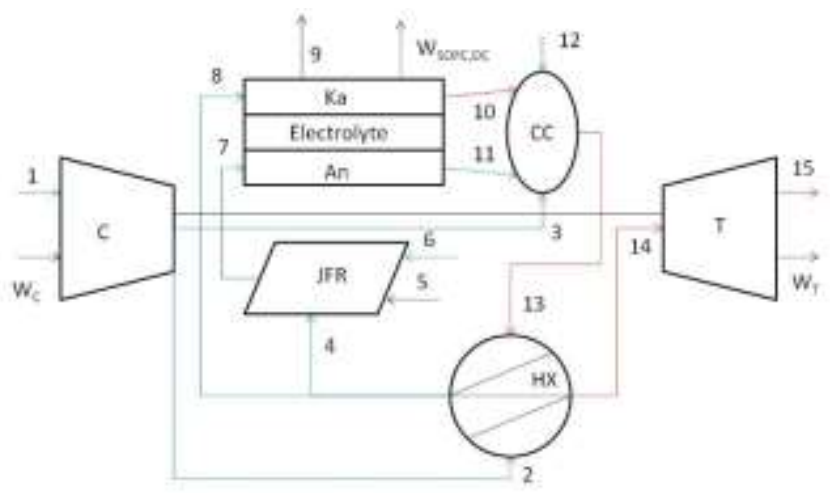

Fig. 1. GT-SOFC Hybrid Auxiliary Power Unit (APU).

The compressor pressure ratio is set between 2 and 4 while the efficiency is assumed to be \%80. The turbine efficiency is assumed to be $85 \%$. Turbine inlet temperature is set to $1400 \mathrm{~K}$. Pressure drop in the system is neglected. Honeywell 131-9A gas turbine APU's weight of $163,7 \mathrm{~kg}$ is used for weight evaluation.

The heat exchanger effectiveness is taken as $85 \%$ while exhaust air temperature is assumed to vary between 700 and $900 \mathrm{~K}$. Accumentrics Cooperation has developed a heat exchanger of $9,61 \mathrm{~kg}$ with an effectivity of $85 \%$, airflow and temperature requirements of which are compatible with the operating conditions of the hybrid system studied in this paper [12].

The jet fuel reformer uses water vapor, air and kerosene to produce $\mathrm{H}_{2}$ and CO. Calculated reformer efficiency is $78,8 \%$. Currently used jet fuel reformers are small scale prototypes. Weight estimation used in this paper was taken from Tornabene et al's predictions as $59,5 \mathrm{~kg}$ [13].

It is assumed that a SOFC stack replaces the APU's $90 \mathrm{~kW}$ electric generator. The necessary SOFC stack weight was calculated as $128,57 \mathrm{~kg}$, assuming a $700 \mathrm{~W} / \mathrm{kg}$ power density. Additional systems' weight such as piping and sealing are neglected. $20 \%$ of the compressor air directed to SOFC through heat exchanger. A summary of assumptions made for components are given in Table IV. 
TABLE IV

COMPONENT PARAMETERS

\begin{tabular}{lc}
\hline \multicolumn{1}{c}{ Component } & Parameter \\
\hline Compressor Efficiency & $80 \%$ \\
Compressor Pressure Ratio & $2-4$ \\
Combustor Efficiency & $95 \%$ \\
Turbine Efficiency & $85 \%$ \\
Turbine Inlet Temperature & $1400 \mathrm{~K}$ \\
Turbine Expansion Ratio & 6 \\
Heat Exchanger Effectiveness & $85 \%$ \\
SOFC Stack Area & $150 \mathrm{~cm}^{2}$ \\
SOFC Fuel Utilization Ratio & $85 \%$ \\
SOFC Air / System Total Air Ratio & 0.2
\end{tabular}

\section{B. Calculations}

Mathematical model and chemical reactions used in gas turbine components (compressor, turbine and combustion chamber) performance evaluations are given in equations 1 to 9.

$$
\begin{gathered}
\frac{T_{2, i z}}{T_{1}}=\left(\frac{P_{2}}{P_{1}}\right)^{\frac{\gamma_{\text {air }}-1}{\gamma_{\text {air }}}}=\pi^{\frac{\gamma_{\text {air }}-1}{\gamma_{\text {air }}}} \\
\eta_{C}=\frac{W_{C, i z}}{W_{C}}=\frac{h_{2, i z}-h_{1}}{h_{2}-h_{1}}
\end{gathered}
$$

$$
\dot{W}_{T}=\dot{\mathrm{m}}_{g a s}\left(h_{15}-h_{14}\right)
$$

$F A R_{\text {Teorical }}=\frac{m_{\text {Fue }_{12}}}{m_{a i i_{3}}}=\frac{n_{\text {Fue }_{12}}}{n_{a i r_{3}}} \frac{M W_{\text {Fuel }_{12}}}{M W_{a i r_{3}}}=\bar{\lambda} \frac{M W_{\text {Fuel }_{12}}}{M W_{a i \xi_{3}}}$

$\eta_{C C}=\frac{F A R_{\text {Teorical }}}{F A R_{\text {Actual }}}$

$\mathrm{C}_{11} \mathrm{H}_{21}+11 \mathrm{H}_{2} \mathrm{O}+5,5\left(\mathrm{O}_{2}+3.76 \mathrm{~N}_{2}\right)$

$\rightarrow 11 \mathrm{CO}_{2}+21,5 \mathrm{H}_{2}+20,68 \mathrm{~N}_{2}+\vartheta_{\text {CC,out }}$

Mathematical model used in heat exchanger is given in equation 10 .

$$
\varepsilon_{H X}=\frac{T_{2}-T_{4}}{T_{13}-T_{14}}
$$

Mathematical model and chemical reaction used for jet fuel reformer are given in equations 11 and 12.

$$
\begin{aligned}
& C_{11} H_{21}+11 H_{2} \mathrm{O}+5,5\left(\mathrm{O}_{2}+3.76 N_{2}\right) \\
& \rightarrow 11 C O+21,5 H_{2}+20,68 N_{2} \\
& \eta_{H_{2}}=\frac{L H V_{H_{2}} \dot{n}_{H_{2}}}{L H V_{\text {Fuel }_{6}} \dot{n}_{\text {Fuel }_{6}}+Q_{J F R}}
\end{aligned}
$$

Mathematical model, chemical and electrochemical reactions used for solid oxide fuel cell are given in equations 13 to 22 .

Anode reaction $\mathrm{H}_{2}+\mathrm{O}^{-2} \rightarrow \mathrm{H}_{2} \mathrm{O}+2 \mathrm{e}^{-}$

Cathode reaction $1 / 2 \mathrm{O}_{2}+2 \mathrm{e}^{-} \rightarrow \mathrm{O}^{-2}$

$V_{F C}=E_{\text {Nernst }}-\eta_{\text {Conc }}-\eta_{\text {Act }}-\eta_{\text {Ohm }}$

$E=E^{0}-\frac{R T}{n_{e} F} \ln \left(\frac{P_{\mathrm{H}_{2}} P_{\mathrm{O}_{2}}^{1 / 2}}{P_{\mathrm{H}_{2} \mathrm{O}}}\right)$

$\eta_{\text {Act }}=\frac{R T}{2 F} \ln \left(\frac{i}{i_{L}}\right)$

$\eta_{\text {Ohm }}=i \cdot \frac{L}{\sigma}$

$\eta_{\text {Conc }}=\frac{R T}{n F} \ln \left(\frac{i_{L}}{i_{L}-i}\right)$

$I_{Y P}=n A \cdot F \cdot j$

$\dot{W}_{F C}=V_{F C} I_{F C}$

$\eta_{\text {th }, \text { SOFC }}=\frac{W_{e .}}{H H V}=\frac{n_{e} F E}{H H V}$

\section{RESUlTS AND CONCLUSIONS}

Total system power and efficiency variation with compressor pressure ratio is given in Figure 2, where a typical gas turbine engine characteristic can be seen. The system's power peaks at the point where the gas turbine components operate at their design point conditions. The maximum efficiency is calculated as $33.2 \%$ for a CPR of 2.6 for the system in this study. 


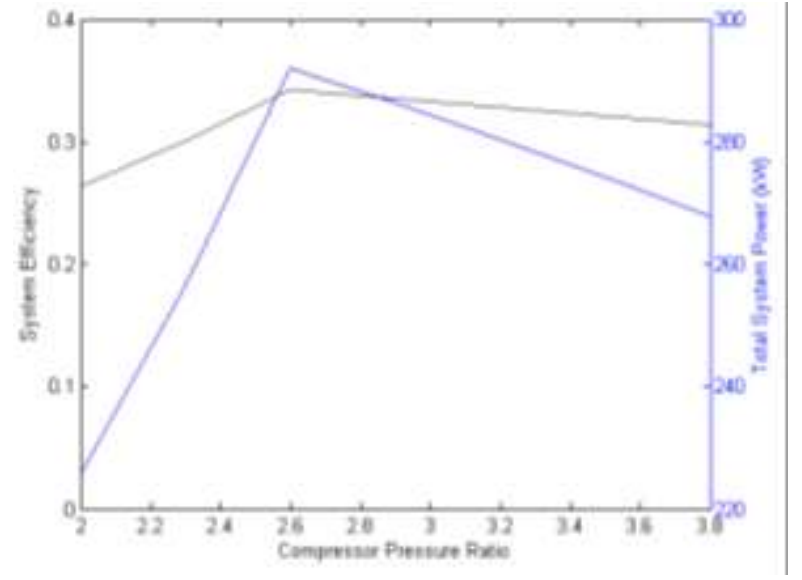

Fig. 2. Compressor Pressure Ratio - System Efficiency and Power

SOFC efficiency and power variation with CPR is given in figure 3. SOFC power increases with CPR while fuel cell efficiency is slightly decreasing. The increase in SOFC power is due to increase in the fuel and air flow rates with CPR. On the other hand, increase in the SOFC operating temperature leads to increase in activation loss, resulting in efficiency loses.

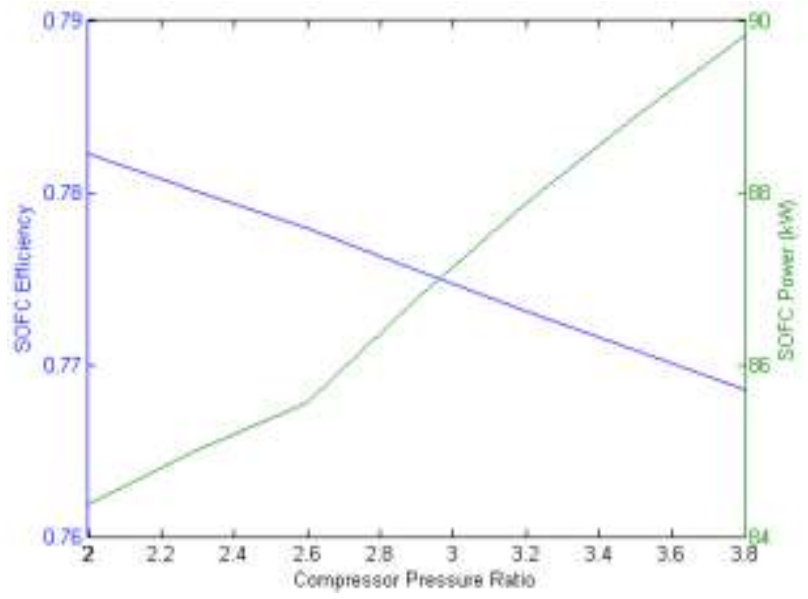

Fig. 3. SOFC efficiency and power variation with CPR

Gas turbine, SOFC and system power variation with CPR is given in Figure 4. The selected gas turbine's maximum efficiency would be $23.2 \%$ if there wasn't a SOFC in the system. The hybrid system's maximum efficiency was increased up to $33.2 \%$ through the SOFC efficiencies of 76 to $78 \%$.

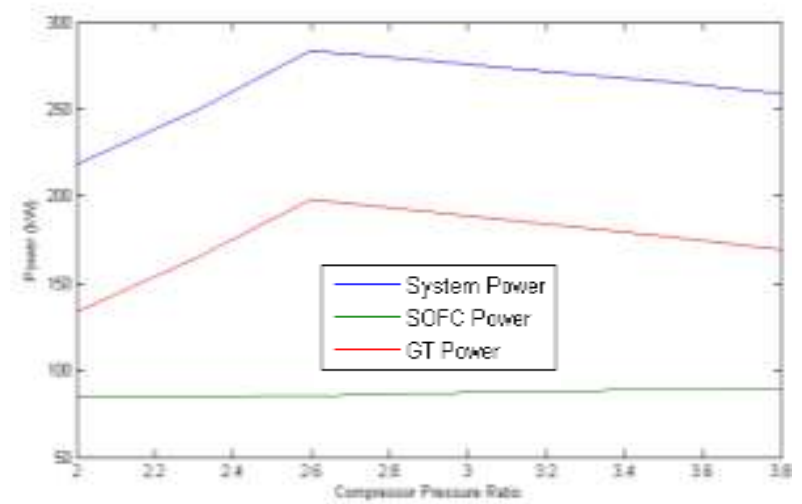

Fig. 4. Compressor Pressure Ratio - Power
The system's fuel consumption and water production rate variation with CPR are given in Fig 5. The hybrid system's fuel consumption is lower than the base gas turbine engine fuel consumption about $120 \mathrm{~kg} / \mathrm{h}$. The hybrid system's fuel consumption is $61.8 \mathrm{~kg} / \mathrm{h}$ and water production is $43.7 \mathrm{~kg} / \mathrm{h}$ at the CPR of 2.6. As the system produces water at a rate of about 40.3 to $50.4 \mathrm{~kg}$ per hour, this much less water can be taken onboard before take-off, for each foreseen/planned flight hour of the aircraft.

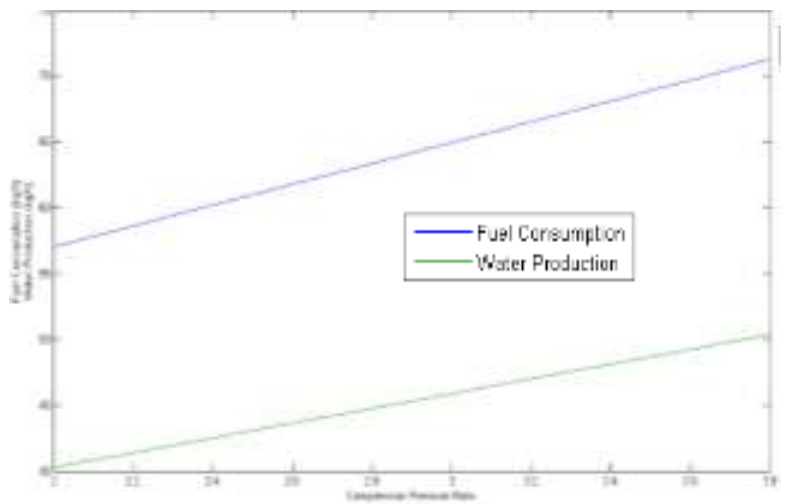

Fig. 5. Compressor Pressure Ratio - Fuel Consumption and Water Production

Increase in weights due to the additional components are shown in Table V.

TABLE V

GAS TURBINE APU - GT-SOFC HYBRID APU WEIGHT COMPARISON

\begin{tabular}{lrrr}
\hline \hline \multicolumn{1}{c}{ Component } & $\begin{array}{r}\text { GT APU } \\
(\mathrm{kg})\end{array}$ & $\begin{array}{c}\text { State of the Art } \\
\text { GT-SOFC APU } \\
(\mathrm{kg})\end{array}$ & $\begin{array}{c}\text { State of the Art } \\
\text { Weight } \\
\text { Difference }(\mathrm{kg})\end{array}$ \\
\hline $\begin{array}{l}\text { Gas Turbine } \\
\begin{array}{l}\text { (Honeywell 131/9A } \\
\text { with 90 kW generator) }\end{array}\end{array}$ & 163.7 & 163.70 & 0,00 \\
$\begin{array}{l}\text { SOFC - 90 kW (700 } \\
\text { W/kg) }\end{array}$ & 0 & 128.57 & 128.57 \\
Heat Exchanger & 0 & 9.61 & 9.61 \\
Jet Fuel Reformer & 0 & 59.50 & 59.50 \\
Water Tank for JFR & 0 & 54,00 & 54,00 \\
System Net Weight & 163.7 & 415.38 & 251.68
\end{tabular}

The system's total weight almost doubles with hybrid system. However, GT-SOFC hybrid system will consume 58.2 $\mathrm{kg}$ less fuel per hour with respect to the reference gas turbine APU, while producing $43.7 \mathrm{~kg}$ water per hour. This means, a total weight saving of $101.9 \mathrm{~kg}$ is possible per flight hour of the aircraft. Variation of the base and the hybrid APU influences on TOW of the aircraft are shown in Figure 6. In our case, the hybrid system recompenses for its weight increase in 2.47 hours of flight. It has to be noted that, the hybrid system will have less environmental effects, as it consumes less fuel than the conventional GT APU, 


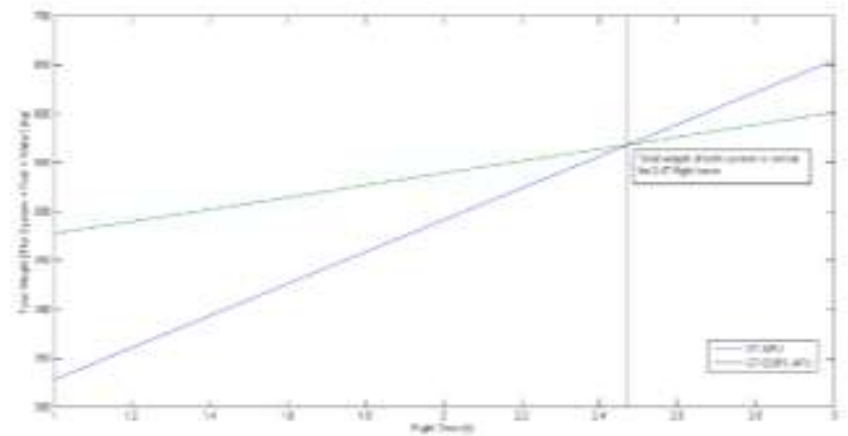

Fig. 6. Total weight variation with flight hour

\section{REFERENCES}

[1] IPCC, 2007: Climate Change 2007: Synthesis Report. Contribution of Working Groups I, II and III to the Fourth Assessment Report of the Intergovernmental Panel on Climate Change [Core Writing Team, Pachauri, R.K and Reisinger, A. (eds.)]. IPCC, Geneva, Switzerland, 104 pp.

[2] Boeing (2015), Current Market Outlook 2015 - 2034. (Retrieved at http://www.boeing.com/resources/boeingdotcom/commercial/about-ourmarket/assets/downloads/Boeing_Current_Market_Outlook_2015.pdf on $01.12 .2016)$

[3] Airbus (2016), Global Market Forecast 2016-2035. (Retrieved at http://www.airbus.com/company/market/global-market-forecast-2016-2 $035 /$ on 01.12 .2016 )

[4] Breit J. ve Moore J. S. (2007). Fuel Cells for Commercial Transport Airplanes Needs and Opportunities. A Collection of the 45th AIAA Aerospace Sciences Meeting Technical Papers Volume 23, 5th AIAA Aerospace Science Meeting and Exhibit Reno, Nevada, 16413 - 16421.

[5] Sinnett M. (2007) 787 No-Bleed Systems: Saving Fuel and Enhancing Operational Efficiencies, AERO Magazine, Boeing Commercial Airplanes (AERO QTR_04.07)

[6] Saravanamuttoo H.I.H., Rogers G.F.C. and Cohen H.. Gas Turbine Theory 5th ed., Prentice Hall, Harlow, England (2001).

[7] Winther M., Kousgaard U. and Oxbøl A. (2006), Calculation of odour emissions from aircraft engines at Copenhagen Airport, Science of the Total Environment, $366218-232$.

https://doi.org/10.1016/j.scitotenv.2005.08.015

[8] Honeywell 131-9A Product Catalogue

[9] Scholz D. (2015) An Optional APU For Passenger Aircraft, $5^{\text {th }}$ CEAS (Challenges in European Aerospace) Air \& Space Conference. 7-11 September 2015, Netherlands. Paper no: 177.

[10] NASA Glenn Research Center (2009), High Power Density Solid Oxide Fuel Cells. Office of Technology Partnerships and Planning Division of NASA Glenn Research Center (Glenn has patented this technology (U.S. Patent No. 7,534,519 B2)

[11] Airbus A320 Water and Waste System, Flight Crew Operating Manuel

[12] Bessette N. (2010), Solid Oxide Fuel Cell Balance of Plant \& Stack Component Integration. Accumentrics cooperation Presentation.

[13] Tornabene R., Wang X., Steffen C. J. Jr. ve Freeh J. E. (2005). Development of Parametric Mass and Volume Models for an Aerospace SOFC/GAS Turbine Hybrid System hakkında rapor (NASA/TM-2005-213819). Cleveland, OH, A.B.D.: NASA Glenn Research Center.

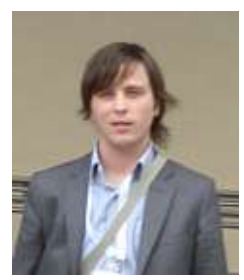

Fatih Tunca was born in Eskisehir, in 1986. He received B.Sc. degree in School of Civil Aviation, Anadolu University, Eskisehir, Turkey, in 2010. His department was Airframe and Powerplant Maintenance. Now he is still M.Sc. student in Department of Airframe and Powerplant Maintenance in Graduate School of Science, Anadolu University.

$\mathrm{He}$ worked in aerospace industry as PROJECT SPECIALIST and LEAD TECHNOLOGY PROGRAMS SPECIALIST for 4 years. He is now GENERAL MANAGER at his own company in Eskisehir. He has published several articles and papers about alternative aviation fuels and environmental effects of Air Transportation. His research interests are Alternative Power Units and Aviation
Fuels for Aircrafts, Fuel Cells, More (All) Electric Aircraft, Unmanned Air Vehicles (UAV), Renewable Energy Sources and Technologies, Hydrogen Energy.

Mr. Tunca applied and granted for a government found (Turkish Republic Ministry of Science, Industry and Technology) which supports entrepreneurs and established his own company so as to develop aircraft maintenance equipments in 2015. 